\title{
Livelihood Strategy of Community Forest Users: A Case from Nawalparasi District
}

\author{
Devi Prasad Poudel, PhD \\ Associate Professor, Central Department of Geography \\ Faculty of Education, Tribhuvan University \\ Email for correspondence: devipoudel1@yahoo.com
}

\begin{abstract}
This paper aims to identify the diversification of livelihood strategies of community forest users of different ecological regions in Nawalparasi district. This paper basically based on primary and secondary sources of information primary information have been collected from focus group discussion, key informant survey and household survey. All the primary data are concerned with forest users of the study area. The forest users of the study area have adopted mainly three types of livelihood strategies i.e. farm based, forest based and off-farm based. The finding of the study shows that livestock farming has occupied major role to achieve the average income from farm based livelihood. The linkages between community forest and livelihood of rural people have been found different in the different ecological regions in the study area. The changing life style of members of community forest users can help to manage the forest and improve the livelihood of rural people with the support of such livelihood options in the study area.
\end{abstract}

Key words: Community forestry, rural livelihood, conservation, resources, farm-based and offfarmed based.

\section{Introduction}

Community forest is one of the strategies adopted for the protection, conservation and development of forest resources and improvement of environment and livelihood. It is a group of people with the common interest of getting a sustained supply of forest products (Ministry of Forests and Soil Conservation [MFSC], 1989). The community forestry program is based on a participatory philosophy, where users are involved in decision making, for the distribution of forests products and benefit sharing according to their specific agreement and understanding. Last few decades have witnessed policy shift from state to local community and their respective local institutions and introduction of participatory forest management (PFM) approach worldwide in order to conserve forests and find livelihood opportunities (Arnold, 2001; Food and Agriculture Organization [FAO], 2008). The forest is a reliable source for livelihood for of surrounding communities through creation of financial capital (FAO, 2006). Though forest itself is a natural capital, it equally plays an immense role to create social, financial and physical capital as prerequisites for basic livelihood. However, it does not mean that the forest is everything and the PFM approach is panacea for all forest management problems. Forest and people's livelihood are interrelated in terms of forest resource use especially in rural areas of the least developing countries like Nepal.

There has been a dependency of rural people on forest from ancient time for firewood, timber, grass, agricultural tools and other domestic needs as well as medicinal herbs available from non timber forest products (NTFPs). All those forest products are an integral part of rural livelihood. The livestock is a part of rural livelihood and is partially dependent on forest as it 
provides fodder and grazing to the livestock (Paudel, 2015). Since late 1970s, the Government Policies in Nepal have focused on encouraging group level organizations to manage natural resources, and thus some of these resources previously controlled by the government are gradually being handed over to community users groups. Farming, forest and livestock are three highly integrated constituents of hill farming system and cannot be separated from each other (Gilmour \& Fisher, 1991). Over the past few decades, Community Based Forest Management (CBFM) has evolved as the key strategy of conservation as well as promoting local livelihood, especially in developing countries like Nepal. All over, Nepal, there are about 17,685 community forest users group (CFUGs), benefiting over 1.45 million households, which is about 35 percent of the total population of Nepal involved in community forestry management program (Department of Forest [DoF], 2013).

Most of rural people in Nepal live in and around the forest. Subsistence agriculture is regarded as the backbone of rural people and livestock is considered as integral part of such agriculture. The rural people mainly depend on forest resources for the fulfillment of their basic needs. Agricultural tools, bedding materials, fodder/grass, firewood etc are obtained from forest. Thus, the livelihood of rural people and forest resources are interlinked to each other. In Nepal, community forestry policy was originally, introduced for environmental conservation, which may have reduced the forest resources necessary for the livelihood of disadvantaged or marginalized people (Dhakal, 2005).

The rural people in Nepal make extensive utilization of the forest resources as a part of their livelihood system. The effectiveness of management of community forest and its consequences on livelihood differ with time and space. Past studies show that the community forest strategies became more effective in the Hills and less in the Terai (Mahat, 1998). Nawalparasi district has been selected as the study area because of its peculiar socio-ecological diversities. This paper aims to identify the diversification of livelihood strategies of community forest users residing different ecological regions in Nawalparasi district.

\section{Data and Methods}

This study is based mainly on primary data collected from the field. To collect necessary primary data from the field, several methods such as interview with semi-structured questionnaire, observation and Focus Group Discussions (FGDs) were used. Data collection tools such as checklist and questionnaires were prepared and used. Secondary data and information were also collected through various published and unpublished documents. There are one hundred and ten community forests in Nawalparasi district, and it was not possible to cover all those community forests in the present study. So, attempt was made to select representative community forests for detailed study. Among 110 community forest users group in Nawalparasi district, a total of 42 community forests were selected for the present paper. The size of the total number of CFUGs selected for this study was determined using stratified sampling (Terai, Inner Terai, and Mid-hills). The size was (area and number of households in participating CFUGs) considered while determining the sample size of the community forest for detailed study. Further, equal allocation method was adopted in determining the number of focus group discussion to be studied in each strata using standard sample size determination formula:

Equal Allocation Method,

$$
\mathrm{N}=\frac{\mathrm{L} \sum \mathrm{N}^{2} \mathrm{~h} \cdot \mathrm{s}^{2} \mathrm{~h}}{\mathrm{~N}^{2} \cdot \mathrm{e}^{2} / \mathrm{z}^{2}+\sum \mathrm{Nh} \cdot \mathrm{s}^{2} \mathrm{~h}}
$$


The equation has determined the size of 42 CFUGs to be studied at $95 \%$ confidence level and 1 unit of error. So the number was equally divided into three strata i.e. 14 CFUGs in each strata (Ecological Zone). Hence, a total of 14 CFUGs were selected from each strata based on the list of CFUGs in each strata using random sampling. Random table was consulted for random selection. After selecting 14 CFUGs from each ecological zone randomly, the size of household interview was determined keeping in view the central limit theorem. According to rule of thumb, if the size of sample is 30 or more, the distribution becomes normal of statistical test can be performed (Daniel \& Terrell, 1995). Following this concept a quota sampling of 42 households in each ecological zone was used for household survey. Hence, the sample size for household survey was 126 (42 households from each ecological zone). Before selecting the household for survey, a list of household involved in CFUGs from 14 CFUGs in each strata were prepared. This was taken as the sample frame for selection of households for interview. Random table was consulted while selecting household randomly.

\section{Results: Farm Based Livelihood}

Agriculture, vegetables, livestock are the major sources of income for rural people livelihood. Table 1 shows the average income of agriculture, vegetables and livestock product.

Table 1. Average Annual Household Income from Livestock, Agriculture Products

\begin{tabular}{lcccccc}
\hline Sources & of & Terai (n=42) & \multicolumn{3}{c}{ Inner Terai $(\mathbf{n = 4 2})$} & \multicolumn{2}{c}{ Mid-Hills (n=42) } \\
\cline { 2 - 7 } Income & Income(Rs.) & Percent & Income(Rs.) & Percent & Income(Rs.) & Percent \\
Crops & 43731 & 43.0 & 41500 & 31.7 & 11497 & 33.7 \\
Vegetables & 6283 & 6.2 & 4703 & 3.6 & 1132 & 3.3 \\
Livestock & 51554 & 50.8 & 84776 & 64.7 & 21446 & 62.9 \\
Total & $\mathbf{1 0 1 5 6 8}$ & $\mathbf{1 0 0}$ & $\mathbf{1 3 0 9 7 9}$ & $\mathbf{1 0 0}$ & $\mathbf{3 4 0 7 5}$ & $\mathbf{1 0 0}$ \\
\hline
\end{tabular}

(Household Survey, 2015).

The above table 1 shows that, livestock rearing is important in terms of income generation. More than 50 percent, 64 percent and 62 percent average income are obtained from livestock in Terai, Inner Terai and Mid-hills of the study area respectively. It indicates that livestock is the first primary sources of income of the Community forest user households in the study area. Agriculture seems to be the second sources of income. More than 43 percent, 31 percent and 33 percent average annual household income come from agriculture in Terai, Inner Terai and Middle Hills respectively.

\section{Crop Based Livelihood}

There is linkage between crop-based livelihood and community forestry directly and indirectly in the study area. Rural people's livelihoods depends on various livelihoods options such as agriculture, vegetables and livestock as well. These livelihoods options are directly and indirectly interlinks to each others in many ways. Basically, cereal crops, cash crops and livestock farming are considered agro-based economic activities, which have played a supportive role to the livelihoods of rural people. Rice, wheat, millet and maize are produced as a major cereal crops in the study area. Rice, wheat and maize are produced in Terai and Inner Terai. Millet is produced in mid-hills area. The production of crops is not so sufficient to meet their needs in middle hill area due to the sloppy narrow and non-irrigated land. Particularly, Arkhala, Machedi and upper part of Bharatipur villages have not so fertile land with the agriculture point of view. Now a days, banana, sugarcane and papaya are newly introduced as cash crops in Inner Terai. 


\section{Vegetable Based Livelihood}

Vegetable such as potato, cabbage cauliflowers peas and beans are also produced, which contribute to the livelihood of local people. Turmeric and ginger are grown in the community forest, initiated by CFUGs, which are undertaken as high value crops. Recently, ginger and turmeric have been practicing to cultivate in a large scale with the commercial propose inside the community forest at community based approach in some places in the study area. It helps to contribute to the rural people's livelihoods by selling high value crops. Table 1 shows that more than six percent average annual income have been derived from vegetable products in study area.

\section{Livestock Based Livelihood}

Livestock farming is more popular (Table 1) in this area due to the development of varieties of grasses such as Epil-Epil, Nappier, Estailo Bhatte ghas (dismodium) Kurjo Lap-Lap etc. More than 95 percent people of this area keep livestock in their shed. Maharaja community forest user groups (CFUGs) have started grass development program in a systematic way. They have 198 hectare of land under this community with the purpose of grass development (Field Survey, 2015). Improved breeds buffaloes, goat and pigs are increasing in this area, but local animals are decreasing day by day due to the shrinkage of grazing land. This has led to replacement of the local animal with some improved breed animals. The people of this area sell milk and meat in the near market for their livelihood. Dairy farming and meat shops are getting developed nearby east-west highway. So, dairy farming and meat sell have become major sources of income in this area due to the development of varieties of grass.

\section{Forest Based Livelihood}

Firewood, timber, fodder, pole and leaf-litters are the major sources of income of community forests. Community forestry is considered a good driving agency for income generation and forest products are major sources of income. Fodder tree varies from one ecological zone to another. The concept of fodder trees for Middle Hills and for Terai belts are different. Unlike those in the hills, farmers in the Terai in general do not grow fodder tree because they have the practice of feeding agricultural by-products as one of the major components of feed stuff. The rural peoples utilize fodder tree species for other purposes, such as making ropes and medicine species vary from in their uses; for example Bhorla (Bauhinia vahlii) is used for three purposes (rope, leaf plates and leaf umbrellas).

There are lots of small industries, based on community forest in the study area. Bell-jam is much popular in rural people as medicine and drinking purpose in summer season. Bisasaya community forest has produced Bell-jam in large scale and they make money by selling it for livelihood. Medicinal herbs like Harro, Barro and Amala is used for making Trifala churna, usedfor various kinds of diseases. Sundari community forest and Dhuseri community forest produce Trifala in large scale. Sajiban farming, Babio, Bhorlo, ginger, Pipla is getting popular in Inner Terai. The focus group discussion reported that, such types of NTFPs based products is not very systematic as the members lack high skilled training. With the development of community forest, it has also linkage with small scale industries.

About eighty five percent of the households use firewood for cooking food in Middle Hills. The regional differences are not so much in the use of firewood for cooking. More than seventy three percent households in Terai and Inner Terai use firewood for cooking. Firewood is 
also used for cooking animal feed (Kundho), among other sources of fuel for cooking is not suitable for making Kundho due to the heavy weight of animal food. The remaining community forests average income is found to be more than three percent in the study area. However, the average income of community forests seems to be low, it occurs from intangible sources of community forestry.

\section{Off-farm Based Livelihood}

Remittance based livelihood and community forestry are indirectly related to each other. According to CF member, all household members do not go to foreign land for remittance, only one or two members go to foreign land and others stay in rural area for their livelihood and some go to forest to collect firewood, grass, bedding material etc. but they do not have lots of money to buy timber wood for making their house, at that time family members come back to the household members from the foreign land and buy timber from the community forest easily and make their home with the help of forest resources. Focus groups discussion reported remittance is becoming more popular income sources for their livelihood maintenance as well as a parameter to measure social status in rural society.

Due to the rapid development of small towns, especially in the Terai and the middle hills, it has altered agro-based livelihood strategies, creating opportunities for off-farm employment. In some places, this change in livelihood strategies has created additional pressure on forests through increased demand for timber and non-timber products. Particularly, the rural people of Middle Hills as compared with Terai and Inner Terai have more sources of remittance. It has played a vital role to contribute the change in livelihood of rural people. As most part of Terai and Inner Terai is accessible with motorable roads and highway, the community forest user groups can be benefitted from the existing industries and business as well as services. Daunne area is famous for hotel business, Rajahar, Bhidabari and Gaidakot are known for industrial enterprises and these activities have provided labour services to the local for their livelihood. Likewise, Daldale bazaar and other market centers have provided various opportunities for the forest user groups of the study area.

Table 2. Household Level Annual Income from Off-Farm Activities

\begin{tabular}{|c|c|c|c|c|c|c|c|}
\hline \multirow[t]{2}{*}{ S. $\mathbf{N}$. } & \multirow[t]{2}{*}{ Activities } & \multicolumn{2}{|c|}{ Terai $(n=42)$} & \multicolumn{2}{|c|}{ Inner Terai $(n=42)$} & \multicolumn{2}{|c|}{ Mid-Hills (n=42) } \\
\hline & & Income & $\%$ & Income & $\%$ & Income & $\%$ \\
\hline 1 & Small industries & 500000 & 32.43 & 125000 & 7.67 & - & \\
\hline 2 & Remittance & 242857 & 15.75 & 285000 & 17.49 & 556799 & 41.03 \\
\hline 3 & Pension & 234000 & 15.17 & 370000 & 22.71 & 240000 & 17.67 \\
\hline 4 & Business & 306333 & 19.87 & 346250 & 21.25 & 390000 & 28.71 \\
\hline 5 & Services & 258315 & 16.75 & 502658 & 30.85 & 171142 & 12.60 \\
\hline Total & & 1541505 & 100 & 1628908 & 100 & 1357941 & 100 \\
\hline
\end{tabular}

(Household Survey, 2015).

Table 2 shows the income from small cottage industries, remittance, pension, business and services. Small industries are mostly found in Terai region and almost one third household level annual income comes from these activities. The Inner Terai, has only seven percent but in Middle Hill there is no such type of source of income. The income from the remittance is the highest in Middle hills and decreasing toward Inner Terai and Terai regions respectively. Pension is also other sources of income, less than twenty two percent forest users have pension in the three ecological region. Business is also attractive sources of income among forest users. More than 
nineteen percent, twenty one percent and twenty eight percent users have business in the Terai, Inner Terai and Middle hills respectively.

Similarly, being involving in service sectors is also alternative source of income. Labour service, government service, private service daily wages etc. have been included under the service. More than thirty percent users do work in different types of services in the Inner Terai. Likewise, more than sixteen percent and twelve percent users do some work in the Terai and mid-hills respectively. Remittance, business, pension and services are the bases of livelihood of rural people. These livelihood options are not directly linked to the community forest. However, the members of CFUGs are engaged in different occupational activities. It can support to conserve the community forest indirectly by using different types of fuel or energy for cooking purpose besides firewood. The changing life style of members of CFUGs can help to manage the forest and improve the livelihood of rural people with the support of such livelihood options.

\section{Conclusion}

Diversification of livelihood strategy is the common characteristics of the rural livelihood. Different types of livelihood options are available, which are directly or indirectly linked with community forests. Livestock agricultural crops, vegetable and products from community forests are major livelihood option of rural people. Agricultural crops, livestock, vegetables and forests are interlinked to each others. More than sixty percent average income achieved from livestock in the Inner Terai. Similarly, about two third average incomes obtained from livestock in the Middle hills and more than fifty percent average income achieved from livestock in the Terai. Similarly, agriculture crop sector seems to be the second source of income in the study area. Likewise, vegetable and community forest products are also considered primary sources of income in the study area. The off-farm activities are small industries, remittance, pension, business and services. Remittance is major sources of income in the Middle hills. More than forty percent CFUGs member average income is from remittance. Similarly, more than twenty eight percent sources of income have business as alternative sources of income in the Middle hills, which is the second largest sources of income, which comprises more than twenty one and nineteen percent in the Inner Terai and Terai respectively. Small industries in Terai, remittance in the Middle hills and services in the Inner Terai is found to be the largest alternative sources of off-farm income in the study area.

\section{References}

Arnold, J. (2001). Forests and People: 25 years of community forestry. Rome: Food and Agriculture organization (FAO) of the United Nations.

Bhattarai, K., Conway, D. \& Shrestha, N. R. (2002). The vacillating of forestry policy in Nepal: Historically manipulated internally mismanaged. International Development planning Review, 24 (3), 315-338. Author.

Bhattarai, M. N. (2001). The Ideological Basis from Nepali Forest Laws Conservation Measures and the Purpose Amenmend. A Journal of Environment, 5 (7), 143 Kathmandu: Ministry of Environment (MoE) Nepal.

Dhakal, B. (2005). Community Forestry Policy Impacts and Alternative Policies for Poverty Alleviation in Nepal, [Unpublished PhD Dissertation]. Submitted to Lincoln University, Christchurch, Newzealand. 
Department of Forest (DoF). (2013). Community Forest User Groups Database Record. Kathmandu: Department of Forests.

Food and Agriculture Organization (FAO). (2006). Better forestry, less poverty: a practioner's guide. FAO Forestry Paper 149. Food and Agriculture Organization of the United Nations, Rome.

Food and Agriculture Organization (FAO). (2008). Forest and People. Retrieved from http://www.fao.org/forestry/home/en/Food and Agriculture Organization of the United Nations, Rome visited on 26th September, 2008.

Gilmour, D. A. \& Fisher, R. J. (1991). Villagers, forests and foresters: the philosophy, process and practice of community forestry in Nepal. Sahayogi Press, Kathmandu.

Ministry of Forests and Soil Conservation (MFSC). (1989). Master Plan for the Forestry Sector Nepal: Revised Forestry Sector Policy. Kathmandu: Author.

Mahat, T. S. (1998). Some Options for Development of Community Participatory Forestry in the Terai Region Nepal. In T. B. S. Mahat \& C. P. Upadhayaya (Eds.), Community Participatory Forestry Development Experience in the Terai Region of Nepal (pp. 31-61). IOF/ ITTO Training and Manpower Development in Community Forestry Project, Pokhara, Nepal.

Paudel, D. (2015). Community Forestry and Rural Livelihood in Nawalparasi District, Westran Nepal, [Unpublished PhD Dissertation]. Submitted to Department of Geography, Tribhuvan University. 